\title{
Article \\ Application of Lean Manufacturing Concepts to Evolving a Policy for Engineering Education
}

\author{
Armando Céspedes-Mota ${ }^{1}$ (D), Dinesh Shenoy ${ }^{2}$ (D) and Leopoldo Eduardo Cárdenas-Barrón ${ }^{1, *(D)}$ \\ 1 Tecnologico de Monterrey, School of Engineering and Sciences, Monterrey 64849, Mexico; acespede@tec.mx \\ 2 Department of Operations Management, FLAME University, Pune 412115, India; dinesh.shenoy@flame.edu.in \\ * Correspondence: lecarden@tec.mx
}

Citation: Céspedes-Mota, A.; Shenoy, D.; Cárdenas-Barrón, L.E. Application of Lean Manufacturing Concepts to Evolving a Policy for Engineering Education. Educ. Sci. 2021, 11, 755. https://doi.org/10.3390/ educsci11110755

Academic Editors: Celina Pinto Leão and Ana Cristina Ferreira

Received: 28 August 2021

Accepted: 26 October 2021

Published: 21 November 2021

Publisher's Note: MDPI stays neutral with regard to jurisdictional claims in published maps and institutional affiliations.

Copyright: (c) 2021 by the authors. Licensee MDPI, Basel, Switzerland. This article is an open access article distributed under the terms and conditions of the Creative Commons Attribution (CC BY) license (https:/ / creativecommons.org/licenses/by/ $4.0 /)$.

\begin{abstract}
This work analyzes the current situation of engineering education in India, especially technical universities characterized by low-quality infrastructure, inflexible curricula, and poor teaching resources including faculty, usually resulting in low student learning and very low graduate placement rates, and identifies the root causes of these problems, summarizes the methodologies adapted by previous researchers in the lean area, and applies the lean manufacturing philosophy to engineering education. This paper applies a value stream map to analyze the current state of engineering education. This technique identifies eight wastes and is given in form of a current state diagram. A future state diagram is presented that recommends solutions to eliminate these wastes. These recommendations make learning processes responsive to needs and provide long-lasting value to students. Overall, it is beneficial in developing a policy for engineering education.
\end{abstract}

Keywords: lean thinking; value stream mapping; learning cell; education policy; administration

\section{Introduction}

Engineering education in India. A graduating engineer should be fully trained and skilled to compete in the ever-changing global economy. Universities that impart engineering training should, therefore, be agile enough to predict these changes and devise methods to ensure the students are fully prepared to meet the challenges. Unfortunately, many engineering colleges in the world are characterized by low-quality infrastructure, inflexible engineering curriculum, and poor faculty, resulting in low student learning and very low graduate employability rates. The principles of lean management, a key industrial engineering concept, have been successfully used by manufacturers to eliminate waste, and these principles are adopted in this work to apply to engineering education.

The setup of engineering education in India is very different from that in other countries. Unlike in developed countries, where engineering degrees are offered by the colleges, the setup in India can be classified into three categories as follows:

Institutions of national importance: this category of institutions in India includes the Indian Institutes of Technology (IITs) [1], and similar institutes that are focused on specialized areas like information technology (e.g., Indian Institute of Information Technology, or IIIT), mining, sugar, fire, textiles, oil, paper and pulp, petroleum, and the like. Other institutes that come under this category are the National Institutes of Technology (NITs) [2]. All these institutes operate independently, have their own governing councils, and have greater autonomy in the design and delivery of the curriculum. The acceptance rate to these institutes is $2-3 \%$. The students that graduate from these institutes are generally considered to be well-trained, and are most preferred by employers.

Government-funded technical universities: several universities in India offer courses in engineering and technology. These universities have one or more affiliated colleges. Students are admitted to and undertake study in one of these affiliated colleges. Students study the curriculum (up to 6 subjects each semester) designed by the university (a small number of these affiliated colleges are given autonomy to design and deliver their courses) 
over 8 semesters or 4 years. At the end of each semester (of roughly about 12 weeks of study) the university conducts an examination. The student progresses to the next semester if he/she successfully clears the examinations for each of the subjects. A student has to complete 8 semesters in a college and successfully clear all the examinations conducted by the university to graduate. Degrees are conferred only by the university, and not by the college where a student undertakes study. A good number of students that graduate from these affiliated colleges are inadequately trained and are often unemployable in the industry as-is. Such students have to undergo some remedial training at an additional cost before securing employment.

Private universities: there also exist some private universities that offer engineering courses. These universities do not have any affiliated colleges. These universities admit students using their screening tests and have the flexibility to design and deliver a curriculum to students.

Problem statement. In all, 3500 engineering institutions admit students to undergraduate engineering degree courses (after completion of 12 years of school education). In the year 2019-2020, for example, a total of 3,225,190 students were admitted to these colleges and universities, per STATISTA [3]. The focus of this paper is the second category of institutions, government-funded technical universities, with affiliated colleges characterized by low-quality infrastructure, an inflexible curriculum and poor teaching resources including faculty, and usually result in low student learning and very low graduate placement rates. This study works by identifying the root causes of these problems, summarizing the methodologies adapted by previous researchers in the lean area, and applying the lean manufacturing philosophy to the engineering education scenario, based on AICTE-CII [4] Only $60 \%$ of the engineering students in India study in these colleges [4], the drop-out rate is $30-35 \%$, and as a result, only $70-75 \%$ of the enrolled students earn an engineering degree, and more than $60 \%$ of the graduating engineers are unemployed, per Dash et al. [5]. No more of the $40 \%$ of engineering graduates end up doing an internship and only $36 \%$ do any projects beyond coursework, according to the National Employability Report [6]. This is equivalent to 2-million-person days of waste.

The rest of this paper is organized as follows. Section 2 presents the stakeholders involved in this problem. Section 3 provides a review of the literature. Section 4 describes the methodology. A future state recommendation is given in Section 5. Finally, Section 6 gives the conclusions

\section{Stakeholders}

Like any other operation, engineering education in India has several stakeholders. Stakeholders include the university, the college where the student is admitted, the regulators like the All-Indian Council of Technical Education (AICTE), a government body that regulates the quality of education, the University Grants Commission (UGC), another government regulator that has oversight of the university functions, and of course the industry (employers), the students and their parents. Figure 1 shows the different stakeholders and their expected interactions in the higher education scenario in India. 


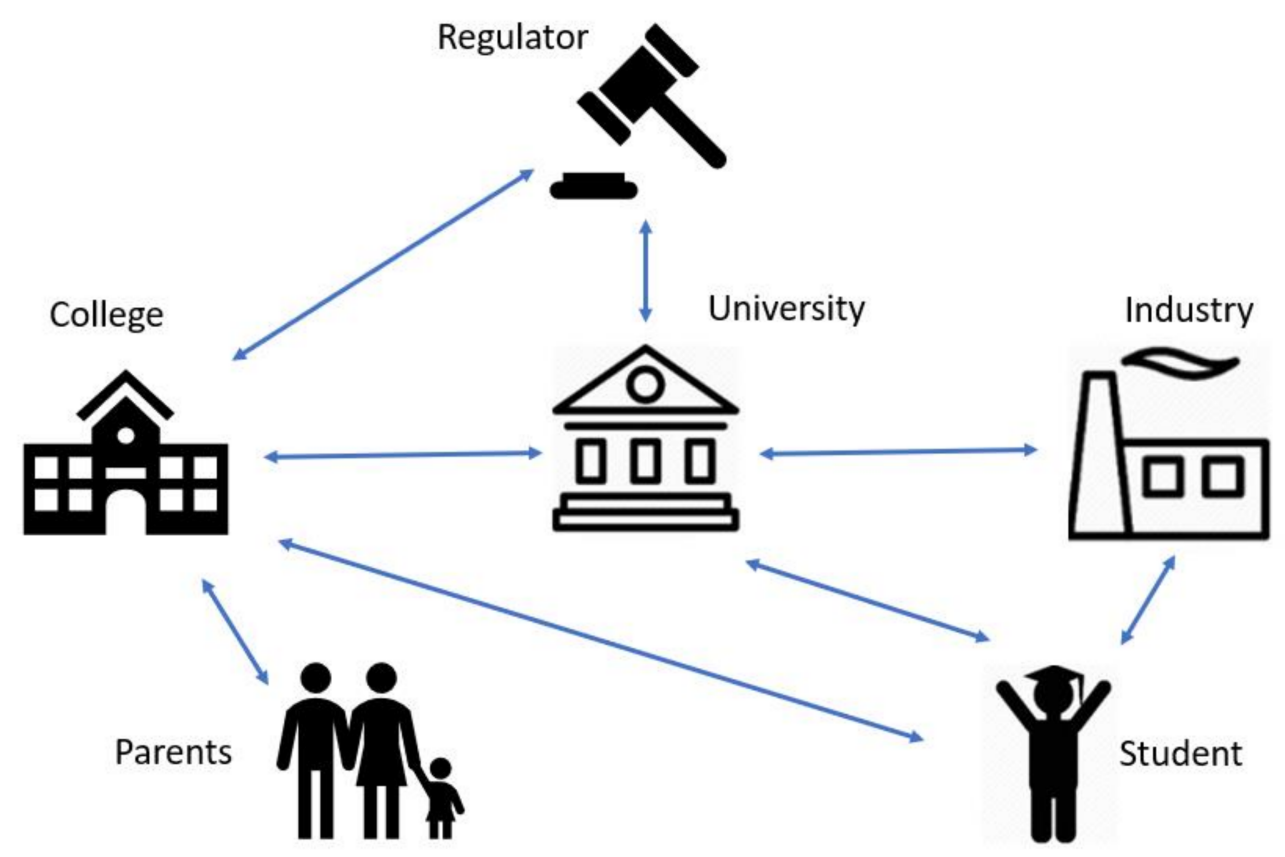

Figure 1. Stakeholders in education.

\section{Literature Review}

Womack et al. [7] define lean as "doing more and more with less and less-less human effort, less equipment, less time, and less space-while coming closer and closer to providing customers with exactly what they want." In other words, the lean philosophy deals with systematically identifying wastes and relentlessly eliminating them. Processes at Ford Motors are often credited with initiating this philosophy in automobile manufacturing, followed by those at Toyota that enhanced these ideas, resulting in now what is referred to as the Toyota Production System (TPS). Since then, lean implementation has seen great benefits in manufacturing, construction, and services. Over the years, many manufacturing organizations have successfully implemented lean processes and have realized desired benefits. Lean concepts have been applied in the services sector as well, and several cases of lean implementation have been reported in the literature. Areas of application in the services sector include healthcare, financial services, public administration, governance, and higher education. Specifically, in the higher education sector, research interests have varied from applying lean to educational administrative functions, such as student registration and faculty hiring, through curriculum development. This section discusses historical work in the domain of Higher Education Institutions (HEI), which forms the basis for our research of evolving a policy for engineering institutions in India.

Comm and Mathiasel [8] provided a framework of how a lean sustainability initiative could be developed and implemented by colleges and universities, and have suggested 8 practices that can be used for this purpose [9]. One of the practices, for example, involves industry, administration, the board of trustees, faculty and staff, and students in making major policy changes at the university. Womack [10] suggests that in HEI, there are 3 processes, "Design, Make and Use," that each learner goes through, and has stressed the identification of value by suggesting that the service provider or the employer is not the beneficiary of education, it is the student; therefore, any process that does not add value to the student learning process must be eliminated. Womack [10] also suggests that there should be no restrictions on the number of components or hours that a student/learner has to undergo.

Tatikonda [11] has argued that the processes for manufacturing and education are very similar, and therefore, lean principles can be used in the operations of HEIs. Just like in manufacturing where raw materials are transformed into work-in-progress and finally shipped to the end customers, students in an HEI undergo a process of value addition 
(i.e., teaching and learning) before they are fully transformed into employable graduates. Waterbury [12] used a panel of experts, including academics and practitioners (Delphi Study), to develop a lean education model and the associated metrics to study the success of the model.

Many processes used in traditional HEIs are not meeting the needs of the stakeholders that they are expected to serve. These processes often take a long time to finish their tasks and add very little value. Balzer [13] has discussed several issues in an HEI, and how lean thinking can effectively eliminate waste. One such issue discussed is the hiring process at a large university, and that usage of value stream mapping helped the lean implementation team reduce the hiring effort by $54 \%$. Dragomir and Surugiu [14] focused their efforts on lean implementation. They discussed the application of lean principles to established universities ( 3 cases) and detailed different steps that were executed in each of these cases. One key take-away is to communicate the success story to each of the university departments where lean has been implemented successfully. Yost [15] explains that lean manufacturing method are beneficial for workplaces as well, to ensure continuous improvements in careers and technical education. Alp [16] contends that there are two main parts to delivering value to students-the first deals with delivering knowledge to the students, while the second deals with the continuous assessment function, including assignments, testing, and grading. Alp [16] has also provided a comparison of traditional education with lean education. Emiliani [17] has described the application of lean principles to the design and delivery of an education program for business students. His study has indicated a higher level of satisfaction, lesser ambiguity in lectures and assignments, and better management of student time. Reddy [18] has identified clusters of educational administration processes and their associated problems. He then systematically identified solutions to each of the clusters using lean tools. Tilforlioglu [19] described that, in a lean education framework, students and teachers collaborate as equal participants, taking decisions together for solving classroom problems while learning from each other. Nemanja et al. [20] emphasized the importance of applying lean principles in higher education institutions focused on the laboratory environment. Martinez [21] describes the importance to prevent redundant activities repeated excessively, also known as overprocessing, evaluating lean education (previous knowledge of the students), and properly planning lean teaching (teaching process). Martinez-Sanahuja [22] analyzed the adaptation of lean principles and practices to teaching in technology subjects, establishing and classifying what issues are non-value-added in education, and detecting how to eliminate them.

According to Jalote, Pain, and Sopory [23], in classification, the universities in a class are grouped by their purpose and mission, and no effort is made to rank them. In this way, 40 universities and 32 engineering institutions were identified as research HEIs in India. Based on the number of full-time Ph.D. students, the number of faculty, research grants, and publications, six universities and eight engineering institutions showed the highest research activity category. The classification of the HEI of a country allows observing the diversity of purpose, and aspirations of different HEI. Nassa, et al. [24] analyse data on five years of Indian rankings to assess their impact on the performance parameters of HEIs in the engineering disciplines on teaching, learning and resources, graduation outcome, outreach, inclusivity, and perception. The authors found that rankings positively influenced the performance of HEIs and could be used as a source of information for guiding policies that are decided according to the needs of the university's environment.

Menon and Suresh [25] have described the enablers that can facilitate agility in faculty members of engineering institutions to help the management of engineering colleges and universities to design, adopt and implement policies and practices to facilitate agility in faculty members. The authors suggest that policymakers should focus on policies and practices that leverage human resource potential and support an innovative climate in engineering institutions. Despite the faculty members (workforce) contributing to the progress of HEIs, very little work has been done on how they can be made agile. Khandan and Shannon [26] cleverly applied the lean thinking methodology in educational methods 
and techniques to increase the level of student engagement and the efficiency of learning, outlining the key waste sources found through face-to-face, online, and hybrid teachinglearning environments, and providing practical implications, counting the non-valueadded issues. With data gathered through a questionnaire from final year undergraduate engineering students, they noticed that online teaching had the greatest effect on student engagement, based on the identification and weighted values of non-value-added issues. The study underlines the essential lean wastes within online, hybrid, and face-to-face teaching, and provides key examples within the stated lean waste to provide solutions to improve student engagement. Mohanty and Dash [27] describe that engineering education in India faces significant challenges as it requires meeting the demands of the technical profession and emerging job market. The authors suggest that it is time to redesign India's curricula and pedagogy, making the teacher preparation program a priority of technical higher education.

\section{Methodology}

In this paper, the problems in delivering high-quality engineering education were reviewed holistically at a government policy level, rather than just focusing on one or two symptomatic concerns. In this research, the focus is on the student learning process, rather than on other administrative processes in colleges and universities. As part of this research, the traditional lean principles as applied to manufacturing organizations, have been adapted to engineering education. This includes the following five steps described by Womack [10]:

1. Identify the primary beneficiary of the engineering education process;

2. Specify value;

3. Map the value stream keeping the product in view;

4. Flow, or let the expected beneficiary of the process pull the value; and

5. Sustain the process with continuous improvements.

The first three steps have been discussed in detail in the following sections of the paper, while the last two are discussed as part of the future state. In this research, the student is the product. The college where the student undergoes training is responsible for transforming the student into an engineer. To do this, the college puts the student through a series of processes. These include learning processes involving theory and practice classes, internships, and project work. At the end of the transformation process the student, now a fully trained engineer, is expected to be absorbed by the relevant industry where he/she continuously applies the knowledge gained.

\subsection{Identify Beneficiary}

The aim of implementing lean in an organization is to ensure the end customer obtains value. The first step is, therefore, to identify the end-customer and define value. In a manufacturing organization, identification of the end-customer is quite easy. This is the organization that pays for the product and is usually the beneficiary. However, in an HEI the organization paying for the product and the beneficiary may be two different people. Womack [10] suggests that, in a university setting, the student is the ultimate beneficiary and therefore must be considered the end-customer. A few other authors (Tatikonda [11], Yost [15]) suggest the use of the traditional approach of considering the employer as the end-customer. In this research, the latter concept is used since this principal focus is on the overall engineering education system in a country.

\subsection{Specify Value}

Next, the concept of value is defined. The employer expects the new hire from the college (i.e., the graduating engineer) to perform and generate valuable outputs by applying knowledge gained in the HEI. Therefore, value is the knowledge, gained through training in the college that is used at the workplace. 


\subsection{Map the Value Stream (Current State)}

Now that the end-customer and value are identified, the next step is to identify wastes to eliminate systematically. Any activity that the student is put through but does not add value should be considered wasteful and must be systematically reduced and finally eliminated from the HEI's learning processes. For this purpose, one of the popular lean manufacturing tools, value stream map (VSM), has been used to visualize and identify wastes. Several researchers and practitioners have successfully used VSM to visualize, identify and eliminate non-value adding processes. The reader is referred to Kaylani et al. [28] and Marudhamuthu et al. [29] for further information on the application of VSM in the manufacturing domain.

From a manufacturing perspective, the purpose of a VSM is to analyze the flow of material and information through the processes. In an HEI, the student is processed and the finished product (i.e., the fully trained engineer) is shipped to the end customer. Figure 2 shows the current state VSM including issues and problems regarding engineering education in India. Please note that the VSM does not include the time map since the focus is not on the time of delivery but the quality and the quantity of the output. A review of the VSM reveals several issues. These issues are discussed in the following sections.

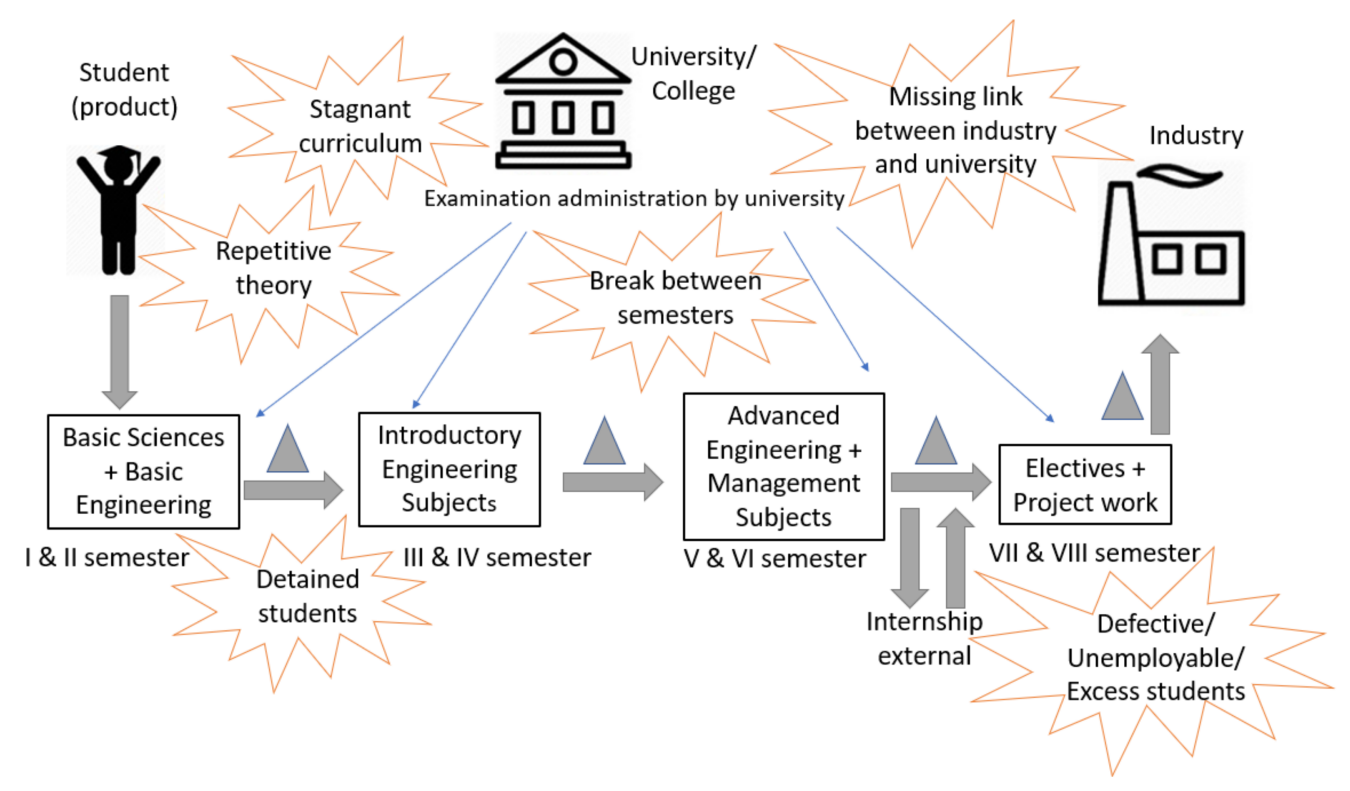

Figure 2. Value stream map (current state).

\subsubsection{Missing Link between Industry and University}

The first issue is that of the missing link between the industry and the university. There is little interaction between the representatives of the industry and the university, and as a result, the following problems can be observed:

1. The number of engineers graduating is far more than what the industry can absorb. Data from the All-India Council for Technical Education (AICTE), the regulator for engineering colleges in India, reveal that of the 1.02 million students that were admitted/enrolled in the academic year 2012-2013, only 0.356 million were employed/placed from campuses, per AICTE-CII [4], and Dash et al. [5]. A recent report, the National Employability Report [6], reveals that $80 \%$ of Indian engineers are not fit for any job in the knowledge economy and only $2.5 \%$ possess the skills in Artificial Intelligence (AI) that industry requires. The report suggests that the government of India needs to prioritize higher education and undertake long-term policy interventions in the next years to amend the low rate of engineering employability. 
2. Problem (1) above, in turn, results in engineering graduates taking up jobs that have no relation to their area of study, per the National Employability Report [6]. This is wasteful.

3. The curriculum is developed by course developers and professors who have little interaction with their industry counterparts, as described in Mohanty and Dash [27]. The curriculum thus developed has very little relevance to the current industry requirements.

4. The curriculum is not self-sufficient, and almost always has some redundancies. For example, a student studying Turbomachinery as part of the third year in Mechanical Engineering needs to study Dimensional Analysis, which is also taught as part of Physics during the first year.

5. Because of (3) above, not all students that graduate are of employable quality, as presented in Mohanty and Dash [27]. Many graduating students, if at all absorbed by the industry, need to be re-trained on the job to meet the expectations of the industry, per the National Employability Report [6].

\subsubsection{Low Barriers to Entry}

The minimum requirement to study in an engineering college is as low as $40 \%$ marks in basic sciences at the school level. While a few state governments conduct a screening test to identify students that can be admitted to engineering courses, these tests are farcical, given the fact that the supply of seats to engineering courses is far more than the total number of seats demanded. In other words, a lot of seats are unfilled. In most circumstances, almost anyone taking the screen test secures admission to an engineering course. This low barrier to entry is one of the main issues in engineering education in India.

\subsubsection{Repetitive Theory and Laboratories}

The students learn basic sciences during their two years of pre-collegiate education. Around $30 \%$ of the same curriculum is taught again during the first year of engineering studies.

\subsubsection{Large Number of Detained Students}

Several universities in India have a system where a student is detained at the end of the first year if he/she does not clear a minimum number of subjects. Even though the students study/repeat the subjects from school in their first-year engineering courses, many students are yet detained. Statistics from different studies and reports reveal that this number could be anywhere between $50 \%$ and $81 \%$.

\subsubsection{Break between Semesters}

Most universities in India have four months of learning followed by 15 days of examinations. A large period of inactivity, usually about 1 month, occurs following the examinations. This break does not help in continuous learning. Unless carrying out an internship, a student is learning only $66 \%$ of the time each year.

\subsubsection{Multitasking}

Each student must study among 6 and 8 disparate subjects and laboratories each semester. These subjects they study each semester are not related to each other. In manufacturing, this is akin to operators performing multiple tasks on the shop floor while producing a product. Multitasking has never been found to be good, and humans invariably make mistakes.

\subsubsection{Incomplete Coverage of Topics}

Not all topics in a subject are taught during the study. Professors and course instructors focus only on topics that are frequently asked on the university-conducted examinations.

Table 1 categorizes these problems in terms of the 8 wastes in the Lean thinking process. 
Table 1. Examples of wastes in higher educational institutes.

\begin{tabular}{|c|c|}
\hline Category of Waste & Examples in HEI \\
\hline Over-production & More trained students are produced than what the industry can absorb. \\
\hline Waiting & Breaks between semesters. \\
\hline \multirow{3}{*}{$\begin{array}{l}\text { Over-processing } \\
\text { Duplication }\end{array}$} & Same topics/subjects being taught at different stages. \\
\hline & Multitasking, $6-8$ subjects to be taken together in one semester. \\
\hline & Incomplete coverage of topics in the curriculum. \\
\hline \multirow[b]{2}{*}{ Transportation } & $\begin{array}{l}\text { Students study in local colleges that are affiliated with universities that are } \\
\text { located elsewhere. These Universities implement rules \& regulations. }\end{array}$ \\
\hline & $\begin{array}{l}\text { Communication between University and College is usually poor and } \\
\text { unclear resulting in students often having to travel to the University to } \\
\text { clarify rules on a case-by-case basis. }\end{array}$ \\
\hline \multirow[t]{2}{*}{ Defects } & $\begin{array}{l}\text { Learning not relevant to industry requirements. Moreover, not all topics in } \\
\text { a subject area are taught to the students. }\end{array}$ \\
\hline & $\begin{array}{l}\text { Poor knowledge acquisition, incorrect learning, failure in examinations. } \\
\text { Many students were detained due to poor performance. }\end{array}$ \\
\hline Inventories & $\begin{array}{l}\text { Need to attend further remedial classes and retake examination before they } \\
\text { can progress to higher semesters. }\end{array}$ \\
\hline & Multitasking. \\
\hline Waste of Talent & $\begin{array}{l}\text { While some students are bright and sharp, their association with a poor college } \\
\text { gets them branded as "weak" and they are not accepted by the industry. } \\
\text { The missing link between industry and University results in the } \\
\text { production of engineers that are not required by the industry. }\end{array}$ \\
\hline
\end{tabular}

\subsubsection{Waste Criteria Analysis}

The waste criteria shown in Table 1 are compared with the corresponding results developed in Martínez-Sanahuja [22] and Khandan and Shannon [26]. In this paper, the focus is more on the student learning process than on other administrative processes in colleges and universities. Also, the problems in delivering high-quality engineering education have been reviewed holistically at a government policy level more than just focusing on one or two symptomatic concerns. The article of Martínez-Sanahuja [22] is oriented to highlight the waste source in lean education (learning process) and lean teaching (contents). In Khandan and Shannon [26], the waste criteria are oriented in the face-to-face, online, and hybrid teaching-learning environments providing practical implications counting non-value-added issues. The results of this comparative analysis are shown in Table 2 as a summary of waste sources in HEI. A combination of the waste criteria described in Martínez-Sanahuja [22] and Khandan and Shannon [26] could be implemented as a future challenge in our work.

Table 2. Summary of waste sources in HEI of three research works.

\begin{tabular}{llll}
\hline Category of Waste & This Paper & $\begin{array}{l}\text { Martinez-Sanahuja [22]. Lean } \\
\text { Education/Lean Teaching }\end{array}$ & $\begin{array}{l}\text { Khandan and Shannon [26]. } \\
\text { Online/Hybrid/Face to Face }\end{array}$ \\
\hline Overproduction & $\begin{array}{l}\text { More trained students than } \\
\text { industry needs, }\end{array}$ & $\begin{array}{l}\text { More degrees produced than } \\
\text { needed/more knowledge } \\
\text { than required. }\end{array}$ & More content than needed. \\
Waiting & Breaks between semesters. & $\begin{array}{l}\text { Waiting for the course } \\
\text { start/Waiting between classes. }\end{array}$ & $\begin{array}{l}\text { Waiting at the start of a course, } \\
\text { to solve technical issues, to } \\
\text { obtain a response to questions. }\end{array}$ \\
& & $\begin{array}{l}\text { To do or repeat academic or } \\
\text { administrative processes/Teach } \\
\text { Overprocessing }\end{array}$ & $\begin{array}{l}\text { Repeat content in course } \\
\text { modules, less time to think in } \\
\text { alanning, excess of practice activities. }\end{array}$ \\
\hline
\end{tabular}


Table 2. Cont.

\begin{tabular}{|c|c|c|c|}
\hline Category of Waste & This Paper & $\begin{array}{l}\text { Martinez-Sanahuja [22]. Lean } \\
\text { Education/Lean Teaching }\end{array}$ & $\begin{array}{l}\text { Khandan and Shannon [26]. } \\
\text { Online/Hybrid/Face to Face }\end{array}$ \\
\hline $\begin{array}{l}\text { Duplication } \\
\text { (Motion in }[22,26] \text { ) }\end{array}$ & $\begin{array}{l}\text { Multitasking, many subjects in one } \\
\text { semester, incomplete coverage of } \\
\text { topics in the curriculum. }\end{array}$ & $\begin{array}{l}\text { Doing irrelevant tasks for } \\
\text { education/teachers doing tasks but } \\
\text { no teaching. }\end{array}$ & $\begin{array}{l}\text { Transitions from one lecture to } \\
\text { another, being late due to } \\
\text { transitions, adjusting the } \\
\text { sitting position. }\end{array}$ \\
\hline Transportation & $\begin{array}{l}\text { Communications between } \\
\text { universities and colleges. }\end{array}$ & $\begin{array}{l}\text { Excess movement from student's } \\
\text { home to university/excess } \\
\text { movement of content, activities, and } \\
\text { materials physically or virtually. }\end{array}$ & $\begin{array}{l}\text { Different communications, } \\
\text { platforms, or handling materials. }\end{array}$ \\
\hline Defects & $\begin{array}{l}\text { Learning not relevant to industry } \\
\text { requirements, poor knowledge } \\
\text { acquisition, incorrect learning, } \\
\text { failures in examinations. }\end{array}$ & $\begin{array}{l}\text { Degrees without the proper } \\
\text { knowledge, skills, and } \\
\text { attitudes/low-quality content, } \\
\text { resources, or methodologies. }\end{array}$ & $\begin{array}{l}\text { Struggle to focus on lecture } \\
\text { content, communication problems, } \\
\text { distractions among peers. }\end{array}$ \\
\hline Inventories & $\begin{array}{l}\text { Students detained due to poor } \\
\text { performance, remedial classes, } \\
\text { and retake examinations. }\end{array}$ & $\begin{array}{l}\text { More graduate students than } \\
\text { required/contents, activities, } \\
\text { materials, technical resources } \\
\text { prepared but not used. }\end{array}$ & $\begin{array}{l}\text { Unused resources, lab } \\
\text { equipment, forgotten equipment. }\end{array}$ \\
\hline Waste of talent & $\begin{array}{l}\text { Brilliant students associated with } \\
\text { low academic level colleges } \\
\text { branded them as "weak" and are } \\
\text { not accepted by the industry. The } \\
\text { missing link between industry } \\
\text { and university. }\end{array}$ & $\begin{array}{l}\text { Teachers, staff, stakeholders, and } \\
\text { students not involved in the } \\
\text { improvement of } \\
\text { education/teachers and students } \\
\text { not involved in the improvement of } \\
\text { the teaching-learning process. }\end{array}$ & $\begin{array}{l}\text { Limited feedback from students } \\
\text { to teaching strategies, limited } \\
\text { time for research activities, } \\
\text { underutilization of free periods } \\
\text { between university lectures for } \\
\text { revision/assignment work. }\end{array}$ \\
\hline
\end{tabular}

\section{Future State Recommendations}

In this section, a conceptual framework for the future state for an HEI is developed, that follows a university-college model in India that addresses the last two points in the lean manufacturing paradigm-flow and continuous improvements. These recommendations could be part of a higher education policy that the Government of India is trying to address the education concerns. Process improvements required for the value stream to flow have also been presented.

\subsection{Industry to Communicate Specifications and Requirements}

A manufacturing organization places orders for raw materials with its suppliers. The supplier's responsibility is to deliver good quality raw materials in required quantities at the required time. Drawing an analogy from this, the organization that finally absorbs the graduating student is considered the ultimate beneficiary in this scenario. Organizations must be able to estimate the number of engineers they would want to employ. Estimation techniques such as Delphi or expert judgement may be used to perform this activity. Once an estimate is available, the managers from the organization should communicate, tradewise, the number of engineers they would want to absorb each year, at least four years in advance, considering the regular duration of an engineering course in India is four years. Information received from all such organizations can be collated. Based on this information, the university can then decide how many students would be admitted to engineering courses each year. This would ensure that the number of students getting into engineering courses would be able to secure employment in these organizations on completion of their course four years hence. This change in process will greatly eliminate the waste of trained human resources. This will also allow the students to flow through the education process seamlessly and get employed in a firm for which they are trained.

\subsection{Create Higher Barriers to Entry}

This change in process will also bring in an associated benefit. Because there would be limitations on the number of students that would be admitted to a course, it would create a sense of competition between prospective students, and only the best and most interested 
would be able to secure admission to engineering courses, thereby, creating a barrier to entry to those that are uninterested. This change in process will greatly eliminate the waste of trained human resources. According to Jalote, Pain, and Sopory [23], it can be suggested that the universities and engineering institutions that they mention in their article have a higher barrier to entry. Moreover, Nassa, et al. [24] describe that ranking can play an important role in setting up a culture of competition, creating higher barriers of entry, and working towards improvements in the performance and quality of the academic institution.

\subsection{Create Learning Cells}

Multi-tasking has never been good for human beings. One interruption that needs to be brought into HEIs is the elimination of multi-tasking. In the current scheme of things, a student is expected to undertake classroom study of six disparate subjects and perform experiments in two laboratories in each semester. Given this, a student attends classes 2-4 disparate subjects spread over 4 to $6 \mathrm{~h}$ each day. This would require the student to flip between two or more subjects each day for the whole semester.

Manufacturing organizations use the concept of cells. While the primary motivation there is to greatly reduce transportation of material, the manufacturing cell concept is adapted to design courses in such a way that the student does not have to keep flipping between several subjects. The university should design courses such that subjects that are related are grouped and are taught in one semester. For example, with regards to the Mechanical Engineering course, the subjects to be taken by a student in, say, semester three would be focused on materials. All relevant topics in physics, chemistry, mathematics, and general mechanical engineering related to materials would only need to be taught in that semester. If a subject unrelated to materials is taught, then that would amount to multitasking and would not bring the best out of the student. This exercise of grouping relevant and like subjects in a semester would require a lot of effort. This would also require some basic changes to the structure of studies-some semesters would have two subjects, while another would have four and yet another would have more. The focus should be on content and subject grouping rather than duration. This would also help the flow of the students from school to employment. Figure 3 illustrates the future state recommendations. It also shows the concept of a learning cell.

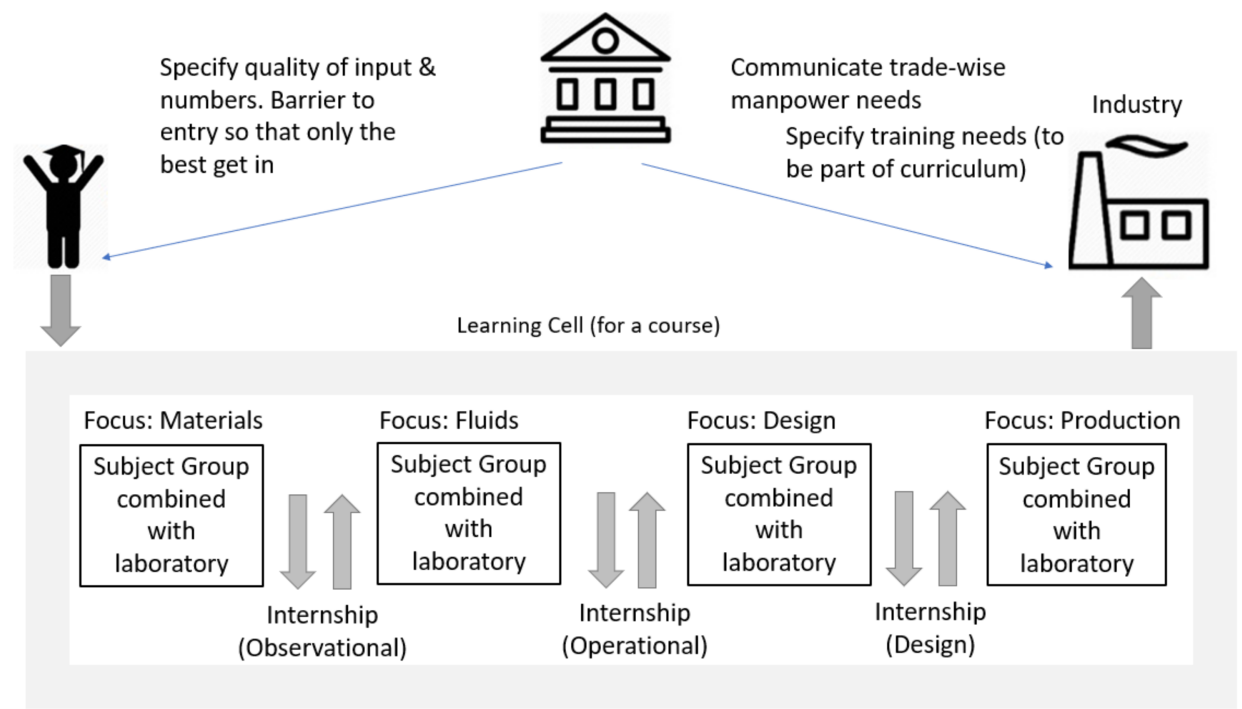

Figure 3. Future state diagram.

\subsection{Mistake Proofing}

A key concept in manufacturing is a Japanese concept called poka-yoke, or mistakeproofing. This concept may not be applied the same way in education as is done in manufacturing and may need to be adapted. Assume that in each semester a mechanical 
engineering student registers to study a subject on strength of materials. A necessary condition to pass this subject must be successful completion of experiments in the strength of materials laboratory. This means that every theory subject must be supplemented with a laboratory where the student is expected to apply concepts learned. This way the concepts are reinforced and the student is expected to perform better when employed rather than making mistakes in the field.

\subsection{Continuous Improvement-Applying Knowledge}

Currently, almost all universities have summer and winter breaks between semesters. This pauses student learning and interrupts the flow. This needs to be avoided. One method to avoid this situation is to place students in the field, i.e., manufacturing organizations, service stations, etc., where actions happen. In the first year of study, students may be asked to just observe and submit reports, which can be evaluated. Between semesters in the second year, the student may be asked to perform basic operations in organizations they are deputed to. In the later years of study, the students should be involved in the design of systems, followed by a comprehensive project to be carried out after all theory and laboratory experiments are completed successfully.

As future work, it would be good to invite some industrial representatives to workgroups for creating more complete coverage of topics in the curriculum.

\section{Conclusions}

Over the years, the quality of engineering education in India has deteriorated, resulting in many graduating engineers being unemployed or taking up jobs that are not relevant to their imparted training. This is wasteful and undesirable. In this paper, the reasons and root causes of the problems are discussed. Lean concepts have been used by manufacturing organizations for several decades now, and almost all have reported significant improvements in savings and customer satisfaction. In this paper, a responsive framework based on lean manufacturing concepts has been developed. If the lean concepts are implemented in earnest, it would result in the elimination of waste (i.e., students would get trained as per requirement and be absorbed by industry without additional training or costs). This would make learning processes more responsive to industry needs and would provide long-lasting value to the ultimate customer. This research recommends having greater coordination between industry and university, creating higher barriers for entry into engineering schools, creating learning cells (or grouping of related subjects in one semester), mistake proofing and internships to be part of a policy that will help improve the quality of engineering education in India, and to learn from other countries what they are doing in lean education, for example in Brazil (Lean Education for Applied Science Universities: A Proposal by Federal Institutes of Applied Sciences in Brazil [30]), in the Philippines (Lean Education in a University in the Philippines [31]), and more (Lean Learning at Oakland University [32], Lean Education at University of Minho: Aligning and Pulling the Right Requirements Geared on Competitive Industries [33], and Postgraduate Studies on Lean Management-A Review of Initiatives [34]).

The current situation of engineering education in India was analyzed in this work, identifying the root causes of low-quality infrastructure, inflexible curriculum, and poor teaching resources including faculty which usually result in low student learning and very low graduate placement rates, that confront technical universities in India. A value stream map was applied that identified eight wastes in a current state diagram, and a future state diagram was presented that recommends solutions to eliminate these wastes. Implementing lean concepts in engineering education in India, the technical employability of engineering graduates would be increased, and universities, students, and industry will grow together. The novel aspect of this paper is the learning cell of a course proposed in Figure 3, which could be extended to all courses in one semester giving a systematic way to give and receive education in engineering universities in India to better graduates' 
employability. Overall, it is beneficial to apply the application of lean manufacturing concepts to evolving a policy for engineering education.

Author Contributions: Conceptualization, A.C.-M., D.S. and L.E.C.-B.; data curation, D.S.; formal analysis, A.C.-M., D.S. and L.E.C.-B.; investigation, A.C.-M., D.S. and L.E.C.-B.; methodology, A.C.M., D.S. and L.E.C.-B.; supervision, L.E.C.-B.; validation, A.C.-M. and D.S.; visualization, A.C.-M. and D.S.; writing—original draft, D.S.; writing—review and editing, A.C.-M. and L.E.C.-B. All authors have read and agreed to the published version of the manuscript.

Funding: This research received no external funding.

Institutional Review Board Statement: Not applicable.

Informed Consent Statement: Not applicable.

Data Availability Statement: Not applicable.

Conflicts of Interest: The authors declare no conflict of interest.

\section{References}

1. Indian Institutes of Technology. Available online: https://iitsystem.ac.in (accessed on 20 August 2021).

2. National Institutes of Technology. Available online: nitcouncil.org.in (accessed on 16 July 2021).

3. STATISTA. Number of Undergraduate Engineering Students in India 2019 by Discipline, Statista Research Department. 23 April 2019. Available online: https://www.statista.com/statistics/765482 (accessed on 12 July 2021).

4. AICTE-CII Survey of Industry-Linked Engineering Institutes. Available online: https://www.pwc.in/assets/pdfs/industries/ education/publication/aicte-cii-pwc-survey-report.pdf.2012 (accessed on 16 July 2021).

5. Dash, M.; Bose, A. Study of Technical Employability of Engineering Graduates in India. J. Entrep. Manag. 2020, 9, 1-6.

6. National Employability Reports, India \& Philippines-SHL. Available online: https://www.shl.com/en/india/employabilityreports / (accessed on 19 July 2021).

7. Womack, J.P.; Jones, D.T.; Roos, D. The Machine That Changed the World. The Story of Lean Production, Toyota's Secret Weapon in the Global Car Wars That Is Now Revolutionizing World Industry; Free Press: New York, NY, USA, 1990.

8. Comm, C.L.; Mathaisel, D.F.X. Less is more: A framework for a sustainable university. Int. J. Sustain. High. Educ. 2003, 4, 314-323. [CrossRef]

9. Comm, C.L.; Mathaisel, D.F. An exploratory study of best lean sustainability practices in higher education. Qual. Assur. Educ. 2005, 13, 227-240. [CrossRef]

10. Womack, J.P. Lean thinking for education. In Proceedings of the Lean Educator Conference, Worcester, MA, USA, 16-18 October 2006.

11. Tatikonda, L. Applying lean principles to design, teach and access courses. Manag. Acc. Q. 2007, 8, 27-38.

12. Waterbury, T.A. Lean in Higher Education: A Delphi Study to Develop Performance Metrics and an Educational Lean Improvement Model for Academic Environments. Ph.D. Thesis, Capella University, Minneapolis, MN, USA, 2008.

13. Balzer, W.K. Lean Higher Education-Increasing the Value and Performance of University Processes; CRC Press: New York, NY, USA, 2010.

14. Dragomir, C.; Surugiu, F. Implementing lean in a higher education university. Constanta Marit. Univ. Ann. 2012, 18, $279-282$.

15. Yost, D.M. Adapting lean principles to career and technical education. Techniques 2016, 91, 50-51.

16. Alp, N. The lean transformation model for the education system. In Proceedings of the 29th Computer and Engineering Conference, Montreal, QC, Canada, 1-3 November 2001; pp. 82-87.

17. Emiliani, M. Improving business school courses by applying lean principles and practices. Qual. Assur. Educ. 2004, 12, 175-187. [CrossRef]

18. Reddy, K.B. Implementation of Lean in Educational Institutions. Master's Thesis, The University of Texas at San Antonio, San Antonio, TX, USA, 2013.

19. Tilforlioglu, F. A new Method in Education: Lean. Turk. Stud. 2017, 6, 811-816.

20. Nemanja, S.; Milovan, L.; Branislava, K.; Jovan, M.; Milovan, M. Improving teaching and learning process by applying Lean thinking. Procedia Manuf. 2018, 17, 595-602.

21. Martinez, S. Teaching innovation projects: Fundamental features to their design, implementation, and evaluation. Rev. Cienc. Pedagog. Innov. 2019, 7, 95-103.

22. Sanahuja, S.M. Towards Lean Teaching: Non-Value-Added Issues in Education. Educ. Sci. 2020, 10, 160. [CrossRef]

23. Jalote, P.; Jain, B.N.; Sopory, S. Classification for research universities in India. High. Educ. 2019, 79, 225-241. [CrossRef]

24. Nassa, A.K.; Arora, J.; Singh, P.; Joorel, J.P.S.; Solanki, H.; Kumar, A.; Trivedi, K. Five Years of India Rankings and its Impact on Performance Parameters of Engineering Educational Institutions in India Pt1 Teaching Learning and Resources Graduate Outcome Outreach and Inclusivity and Perception. DESIDOC J. Libr. Inf. Technol. 2021, 41, 20-36. [CrossRef] 
25. Menon, S.; Suresh, M. Enablers of workforce agility in engineering educational institutions. J. Appl. Res. High. Educ. 2021, 13, 504-539. [CrossRef]

26. Khandan, R.; Shannon, L. The Effect of Teaching-Learning Environments on Student's Engagement with Lean Mind-set. Educ. Sci. 2021, 11, 466. [CrossRef]

27. Mohanty, A.; Dash, D. Engineering Education in India: Preparation of Professional Engineering Educators. J. Hum. Resour. Sustain. Stud. 2016, 04, 92-101. [CrossRef]

28. Kaylani, H.; Almuhtady, A.; Atieh, A.M. Novel Approach to Enhance the Performance of Production Systems Using Lean Tools. Jordan J. Mech. Ind. Eng. 2016, 10, 215-229.

29. Marudhamuthu, R.; Krishnaswamy, M.; Pillai, D.M. The development and implementation of lean manufacturing techniques in Indian garment Industry. Jordan J. Mech. Ind. Eng. 2011, 5, 527-532.

30. Uébe Mansur, A.F.; Leite, F.C.; Bastos, H.P.P. Lean Education for Applied Science Universities: A Proposal by Federal Institutes of Applied Sciences in Brazil. In Lean Education: An Overview of Current Issues; Alves, A., Flumerfelt, S., Kahlen, F.J., Eds.; Springer: Cham, Switzerland, 2017; pp. 25-40.

31. Siriban-Manalang, A.B. Lean Education in a University in the Philippines. In Lean Education: An Overview of Current Issues; Alves, A., Flumerfelt, S., Kahlen, F.J., Eds.; Springer: Cham, Switzerland, 2017; pp. 41-52.

32. Flumerfelt, S.; Ross, W.; Wade, D. Lean Learning at Oakland University. In Lean Education: An Overview of Current Issues; Alves, A., Flumerfelt, S., Kahlen, F.J., Eds.; Springer: Cham, Switzerland, 2017; pp. 77-84.

33. Carvalho Alves, A.; Sousa, R.; Dinis-Carvalho, J.; Moreira, F. Lean Education at University of Minho: Aligning and Pulling the Right Requirements Geared on Competitive Industries. In Lean Education: An Overview of Current Issues; Alves, A., Flumerfelt, S., Kahlen, F.J., Eds.; Springer: Cham, Switzerland, 2017; pp. 149-175.

34. Bednarek, M.; Buczacki, A.; Bielakowski, L.; Gladysz, B.; Bryke, M. Postgraduate Studies on Lean Management-A Review of Initiatives. Educ. Sci. 2020, 10, 197. [CrossRef] 